\title{
The Girls of Jamia
}

\section{Aamir Aziz}

(Translated from the original 'Jamia ki Ladkiyan' in Urdu by Rashmi Varma)

They unmask kings

they launch revolutions through subtle glances

the girls of Jamia

As they tear apart the garb of patriarchy, people clear the path ahead

when they embark stubbornly on their journey

the girls of Jamia

And when the police raise their batons, and the people throw stones

Authors. This article is issued under the terms of the Creative Commons Attribution NonCommercial Share Alike License, which permits use and redistribution of the work provided that the original author and source are credited, the work is not used for commercial purposes and that any derivative works are made available under the same license terms.

and when people begin to pay obeisance to injustice and power and when the slaves tire of fighting the masters

when the broken shards of humanity fall in pieces on the road they clench their fists and raise a cry

the girls of Jamia 
when debased men fall even further

and stars appear to take a first look at them before ascending the skies they clench their fists and raise a cry

the girls of Jamia

When the embers imprisoned in the kitchen fires ignite torchlights and the melancholic sounds of prisoners' chains become the rousing call of freedom they clench their fists and raise a cry the girls of Jamia

They sound the death knell of the autocrat as the oppressor's land quakes and reality merges with dreams they are neither someone's mother, nor daughter, nor wife, nor sister the girls of Jamia

They are no one's honour, no one's pride, no one's home, no one's life they live life, they also smoke cigarettes they are the embodiment of a carefree life the girls of Jamia

So keep your views to yourself, if need be, take cover in a hijab 
they are experts in splitting hairs

the girls of Jamia

In the revolutionary songs inscribed on history's pages

in the verses written in the holy book

in their hearts and their minds, all the world's women are

the girls of Jamia

Aamir Aziz is an actor, singer and poet based in Mumbai.

Rashmi Varma teaches English and Comparative Literary Studies at the University of Warwick.

(Translator's Note: This poem is Aamir Aziz's tribute to the women students of Jamia Milia Islamia whose campus was invaded by police on 15 December 2019. The students of the university had been protesting the discriminatory Citizenship Amendment Act that had been introduced by the government. Many of the women students who had been at the forefront of the protests were injured in the violence. I hope this translation captures some of the dynamism and rebellious energy that was aroused when Aamir Aziz read and performed this poem during the protests. The poem catapults the young women protestors to the real and imaginative centre of resistance.) 


\section{My Mother}

\section{Rehna Sultana}

(Translated from the original in Miya dialect by Shalim M Hussain)

I was dropped on your lap my mother

Just as my father, grandfather, great-grandfather

And yet you detest me, my mother,

For who I am.

Yes, I was dropped on your lap as

a cursed Miyah, my mother.

You can't trust me

Because I have somehow grown this

beard.

Somehow slipped into a lungi

I am tired, tired of introducing myself

To you.

I bear all your insults and still shout,

Mother! I am yours!

Sometimes I wonder

What did I gain by falling in your lap?

I have no identity, no language

I have lost myself, lost everything

That could define me 
And yet I hold you close

I try to melt into you

I need nothing, my mother.

Just a spot at your feet.

Open your eyes once mother

Open your lips

Tell these sons of the earth

That we are all bothers.

And yet I tell you again

I am just another child

I am not a 'Miyah cunt'

Not a 'Bangladeshi'

Miyah I am,

A Miyah.

I can't string words through poetry

Can't sing my pain in verse

This prayer, this is all I have.

Rehna Sultana is an independent researcher, community worker and woman activist working in the Char-Chapari (the riverine) areas of Assam on citizenship and different issues faced by women. She is the lone woman Miya poet. Sultana recently completed her Ph.d from Gauhati University.

Shalim M Hussain is a writer, translator and researcher based in Guwahati and New Delhi. 


\section{Write Down 'I am a Miya’}

Hafiz Ahmed

Write

Write Down

I am a Miya

My serial number in the NRC is 200543

I have two children

Another is coming

Next summer.

Will you hate him

As you hate me?

write

I am a Miya

I turn waste, marshy lands

To green paddy fields

To feed you.

I carry bricks

To build your buildings

Drive your car

For your comfort

Clean your drain 
To keep you healthy.

I have always been

In your service

And yet

you are dissatisfied!

Write down

I am a Miya,

A citizen of a democratic, secular, Republic

Without any rights

My mother a D voter,

Though her parents are Indian.

If you wish kill me, drive me from my village,

Snatch my green fields

hire bulldozers

To roll over me.

Your bullets

Can shatter my breast

for no crime.

Write

I am a Miya

Of the Brahamaputra

Your torture 
Feminist Dissent

Has burnt my body black

Reddened my eyes with fire.

Beware!

I have nothing but anger in stock.

Keep away!

Or

Turn to Ashes.

Dr. Hafiz Ahmed is a writer, teacher and political commentator. He is the president of the Char-chapori Sahitya Parishad, Assam. 


\section{Hindustaani Musalmaan}

\section{Hussain Haidry}

(Translated from the original in Urdu by Husain Haidry)

As I smoked by the roadside,

I hear the muezzin's call break the silence

A reminder, that it was time to pray and then a thought crosses my mind,

'What kind of Muslim am I?'

Am I a Shia or a Sunni?

Am I a Khoja or a Bohri?

Am I from a village or from the city?

Am I a rebel or a Sufi?

Am I devout or a fraud

What kind of Muslim am I?

Am I the kind who kneels in payer or a Jhatka enduring heretic?

Do I wear the skullcap or am I the clean shaven dissident?

Do I recite the aayats of the Quraan or do I hum songs that belong to films?

Do I chant Allah's name or rebel against Sheikhs?

What kind of Muslim am I?

I am an Indian Muslim.

I am from the South, and from the North,

I am from Bhopal, from Delhi, 
From Gujarat from Kashmir

I'm from every caste high and low

I am the weaver, I am the cobbler

I am the doctor, and also the tailor

In me reside the shlokas of the Bhagvad Gita,

As much as the editorials of an Urdu newspaper

Hallowed is the month of Ramadan to me,

As is washing my sins away at the Holy Ganges,

I live life by terms that I myself own,

I've had a drink or two and also smoked,

There is no politician who runs in my veins,

No political party has me in their constraints

I am an Indian Muslim

I am Delhi's Bloody Gate

I am the Labyrinth of Lucknow

I am the demolished dome of Babri,

I am the blurry borders within the city,

I am the poverty of the slums,

I am the Madrasa's broken ceiling

I am the ember that erupts in riots,

I am the garment stained in blood.

I am an Indian Muslim. 
The Temple's threshold is mine,

The Mosque's minaret is mine,

The Gurudwara's hall is mine

The church's pews are mine

I am fourteen percent of a hundred strong

But these fourteen are by no means few

I am the sum of all hundred beings,

And the hundred are a sum of me

Don't look at me with those singular gazes,

I don't have just one, but a hundred faces

I have a character with a hundred layers,

I am a story written by a hundred pens

I am as much an Indian as I am a Muslim

I am an Indian Muslim

I am an Indian Muslim

Hussain Haidry is a poet, lyricist, and a screenwriter based in Bombay. He began his career with poetry and is presently working on songs and screenplays of upcoming movies and web series. 


\section{Ayega Inquilab}

\section{Nabiya Khan}

(Translated from the original in Urdu by Taikhum Sadiq)

Pervading through the silence of the seas,

In the eye of a storm, a resistance plies

Draped in a veil, in a woman's guise

The revolution will rise.

On occasions, in the voice of Gauri,

On occasions, in the dreams of Savitri

Like an aegis for Fatima,

and the son of a mother in despair.

With fervor like fire, untethered, mobilized

Draped in a burqa, bindi, bangles, a woman's guise

The revolution will rise.

In the emphatic evenings of Shaheen Bagh

In the slogan-laden chronicles of Jamia

Surrounded by the dissidents of Aligarh

In voice like the elegies of Faiz

To settle the scores of your injustice, oppression and lies. 
Draped in a burqa, bindi, bangles, a woman's guise

The revolution will rise.

Like the face of my beloved, in a city filled with gloom

The browning leaves will turn into a chinar in bloom

In the light of what was stolen, the righteous will rebel

As the world will break out of, a tumultous spell.

And as the war drums begin to sing

The songs of love, of flowers and skies

Draped in a burqa, bindi, bangles, a woman's guise

The revolution will rise.

When the earth is scorched, by the bitterness of Savarkar

The justice of Ambedkar, will send torrents down the sky

And in the clear sky, a falcon of truth will then soar

As you vanish into nothing, like the Fuhrer had once.

To lay waste to your masquerade, to witness your demise

Draped in a burqa, bindi, bangles, a woman's guise

The revolution will rise.

Nabiya Khan is a poet, and an activist. 


\section{Samvidhan / The Constitution of India}

\section{Kaushik Raj}

(Translated from the original in Hindi by Taikhum Sadiq)

Barging through the doors of your detention camp

I stand, and reproclaim the Constitution of India

Each and every word of which

stands in truck with every fascist brick,

like the first ray of sunlight stands against the dying of the light.

Nazi bricks, as feeble as they are,

cannot stand the Preface of my Constitution,

Mere flicking of its pages, will send shivers down the spine

of your detention camp.

And as it crumbles to the ground

I will stand, on it, and reproclaim the Constitution of India,

I will reproclaim it today, my feet on the corpse of your camp,

so that tomorrow I don't have to stand on a pile of headless corpses.

Corpses, who's severed heads should be decorated,

on the flag of the nation that built these camps,

signalling the downfall of the nation.

For how long do we sing eulogies for the nation,

while looking eye to eye with those severed heads? 
I haven't taken my Constitution from the corridors of the Parliament

Who's death has been presumed as deep slumber,

and hopes from it, lay slaughtered

My Constitution is covered in soil,

I have unearthed it from the ruins of Babri.

My Constitution is drenched in tears,

I have summoned it from bosom of the Jhelum

My Constitution is bathed in red

Rescued from the gurgling blood-streams of Dadri

A sword hangs over the head of my Constitution

But fear, withholds us from touching the hilt.

I have gathered shreds of my Constitution

from the alleys of Hashimpura.

My Constitution, bereft of peace,

cries for a revolution.

Prime Minister, since you have legislated to hold the pen

That can sign off someone's right to be an Indian,

I legislate, that my country stands naked

In the face of a harsh winter,

Your bill will be fed to fires that warm it.

I legislate, that the principles of your Parliament

and the roads of my nation, are cratered.

Your bill will be shredded to fill these craters. 
I legislate, that my nation is dying of hunger,

It will devour your bill whole.

You also deem to legislate our reactions, and fathom our optimism, to the autocratic declarations of your state.

But if you deem to legislate the color of the ink drawn from my blood, that embellishes my palms, I legislate, that the color will be pale.

I retort, by enunciating the Article 14 of the Indian constitution, an article that will bury your bill, deep into the ice of time.

"The State shall not deny to any person equality before the law or the equal protection of the laws within the territory of India." I legislate, that the question of "proof of citizenship" be answered, With the resounding words of this article.

Words, that need to be etched on the walls of government offices With a declaration, that before the words of this article begin to crumble, the bill of discrimination crumbles to the ground.

I wish to gift you, O' President, a new pen.

While signing the this bill of bigotry, and ringing the death knell of secularism 
you broke the nib of your pen

The sound of which resonated with the shattering

of Bismil and Ashfaq's dreams.

I wonder why is the country is still asleep?

I legislate, to erase all the signs of equality,

To rob the mustard fields of their color,

To snatch the blue from the arms of the sky

I legislate, to color them in the color

of the decomposing ideals of the Constitution.

I legislate to color each and every speck of nature

that blankets the idea of unity in diversity, in the color red.

I want the color of sweat to turn blood red too,

At least the nation will turn to the streets someday for it.

I would have also resorted to silence

I wouldn't have reproclaimed the Constitution

But I want the words of this esteemed doctrine

to envelope your tongue,

Before they are erased from the white of their paper

When future generations will implore my stand,

I will tell them, I reproclaimed the constitution

I leave this question for you too.

Where were you, when the nation was crumbling? 
Kaushik Raj is a Delhi-based student, writer and poet. He writes and performs poems on social and political issues.

Taikhum Sadiq is an Urdu poet and translator Udaipur, India. He has published two e-books and has translated a wide range of Urdu poems into the English. He is currently working on publishing his first anthology of Urdu poems and another anthology of the translated works of Parveen Shakir. 


\section{Come Walk with Me}

\section{Taikhum Sadiq}

(Translated from the original in Urdu by Taikhum Sadiq)

In the heart of your words, let cinders seethe, come walk with me

To save our constitution, to set it free, come walk with me

You're government is not your country, they lied to you

To bury this lie, to see it drown in the sea, come walk with me

Come carve a path with the vision of the Bismil's India

To awaken Ashfaq from his syncope, come walk with me

Power has disillusioned the men who sit near the crown

It's time they have a truck with reality, come walk with me

The tyrant has forgotten what the people have a heart

To remind them, this is a democracy, come walk with me

He gave up his body his youth and kissed the gallows for us

To uphold the words of Bhagat Singh's decree, come walk with me

A nation stood welcoming our ancestors with open arms

To tell the world why, they did not flee, come walk with me 
The tyrant is hell bent on building prisons across the nation

To smash open the fascist, lock and key, come walk with me

Rather than suffering in silence for eons, it is better I believe

We raise our voices, and disagree, come walk with me

The tricolor, is our true flag, in our hearts and in our words

To bury the fascist flag in its own debris, come walk with me

I had promised this land, that I will stand with it O'Sadiq

It is time, I fulfill my guarantee, come walk with me.

Taikhum Sadiq is an Urdu poet and translator Udaipur, India. He has published two e-books and has translated a wide range of Urdu poems into the English. He is currently working on publishing his first anthology of Urdu poems and another anthology of the translated works of Parveen Shakir. 


\section{Haq-parastoñ ke Naam \\ (To the Seekers of Truth)}

(Translated from the original in Urdu by Iqra Khan)

There were ages before today,

Fearsome were the kings of the day,

There were despots almighty proclaimed;

And tyrants villanous and famed.

There were scribes who scribbled at their feet,

Their quills fettered to decrees supreme.

Among them were the mavericks from the tales,

Rebellious sparks that raged and raged.

This is to those who stepped forward,

The journalists and the poets slaughtered,

The chroniclers of might and right,

The lords of the letter and the light.

Before whose pens tyranny would prostrate,

Whose verses freed the living enslaved,

Freed life from its fearful state.

Such virtue that patrons and their grants were afraid,

Such courage that decrees of silence failed.

Truth, the pride of their struggles,

Truth, the exploit of their wrangles.

The bearers of the lightning bolt, 
All wrath and insolence, behold,

In facts alone lay their faith,

Apostates of fortune,

Apostates of fate.

Great shepherds of the nation,

Lost to a wilderness of oblivion.

Enchanted by the tricks of a magician-clown,

My country gasps and flounders and drowns.

He sells poisonous dreams and delusion,

No one to snip the blindfolds, end the illusion,

Precious anklets for his people he buys,

Few to tell they're shackles in disguise.

My country succumbs to a crusade over a lie,

The seekers of truth find nothing to get by,

My country worships the darkness of the nights,

Alas, the heralds of dawn may never rise.

Iqra Khan is a law graduate, and a bilingual poet of social justice for subaltern groups in South Asia.

\section{To cite this poetry:}

'Poetry of Resistance', (2020), Feminist Dissent, (5), 280-301. Retrieved from: https://doi.org/10.31273/fd.n5.2020.770 